\title{
SUBLETHAL EFFECT OF NEEM EXTRACT ON MEDITERRANEAN FRUIT FLY ADULTS ${ }^{1}$
}

\author{
MÁRCIO ALVES SILVA², GERANE CELLY DIAS BEZERRA-SILVA², \\ JOSÉ DJAIR VENDRAMIM ${ }^{4}$, THIAGO MASTRANGELO 5
}

\begin{abstract}
The sublethal effect of extracts of Azadirachta indica on Ceratitis capitata was evaluated. Two pairs of flies were treated in plastic tubes with cotton placed in plastic cages. An artificial diet (hydrolyzed protein + sugar) was provided ad libitum. The extracts affected significantly the longevity of C. capitata. The pre-oviposition period were not significantly affected by the extracts. The $A$. indica branches extracted with dichloromethane $(888 \mathrm{ppm})$ affected significantly the fecundity and fertility, reducing the number of eggs laid to approximately $80 \%$ and the egg hatching by $30 \%$ at the $8^{\text {th }}$ day. Therefore, the neem branches extracted with dichloromethane affected the reproduction of $C$. capitata.
\end{abstract}

Index terms: Fruit fly, Azadirachta indica, allelochemicals.

\section{EFEITO SUBLETAL DE EXTRATOS DE Azadirachta indica SOBRE ADULTOS DE Ceratitis capitata}

RESUMO - Neste estudo, avaliou-se o efeito subletal de extratos de Azadirachta indica sobre Ceratitis capitata. Os tratamentos em um tubo plástico com algodão foram expostos para dois casais numa gaiola plástica. Nessa gaiola, também foi fornecida dieta artificial (proteína hidrolisada + açúcar) ad libitum. Os extratos afetaram significativamente a longevidade de $C$. capitata. O período de pré-oviposição não foi significativamente afetado pelos extratos. Em contrapartida, o extrato de ramos em diclorometano (888 ppm) afetou a fecundidade e a fertilidade, reduzindo em $80 \%$ o número de ovos colocados e a viabilidade dos ovos em $30 \%$, no $8^{\circ}$ dia. Portanto, o extrato de ramos em diclorometano afeta a reprodução de C. capitata. Termos de indexação: Moscas-das-frutas, Azadirachta indica, aleloquímicos.

\section{INTRODUCTION}

Derivatives of the neem tree, Azadirachta indica A. Juss (Rutales: Meliaceae), have a wide range of effects against pests, including physiological effects (insect growth regulation and sterility) and the inhibition of host selection (feeding and oviposition inhibition). Azadirachtin, a limonoid that occurs in plants of the genus Azadirachta, is a welldocumented example of a terpenoid that promotes the inhibition of host selection and physiological effect on insects (MORDUE [LUNTZ] et al., 2005); additional limonoids present in neem trees also promote these effects (MORDUE [LUNTZ] et al. 2005).

Investigations with derivates of neem have revealed physiological and behavioral effects against Tephritidae fruit flies. Derivates from neem promoted the inhibition of oviposition (CHEN et al., 1996; SINGH; SINGH, 1998) and had an effect on meta- morphosis (STARK et al., 1990; VAN RANDEN; ROITBERG, 1998b; SILVA et al., 2011), reproduction (VAN RANDEN; ROITBERG, 1998a; DI ILIO et al., 1999; SINGH, 2003; KHAN et al., 2007), longevity (STARK et al., 1990; VAN RANDEN; ROITBERG, 1998a; KHAN et al., 2007) and flight ability (STEFFENS; SCHMUTTERER, 1982). However, neem derivates have low toxic effects on adult Tephritidae fruit flies (BARRY et al., 2005; EFROM et al., 2011). In this study, it was investigated the sublethal effect of neem extract on adults of the Mediterranean fruit fly (medfly), Ceratitis capitata (Wied.) (Diptera: Tephritidae), by evaluating the effects of the neem extract on the reproduction and longevity of the medfly. The suggested hypothesis is that neem extracts could induce drastic physiological effect during the period of vitellogenesis in females. The observed physiological effects of the neem extracts (limonoids) on the insects are quite con-

\footnotetext{
1(Trabalho 102-12). Recebido em: 28-02-2012. Aceito para publicação em: 07-01-2013.

${ }^{2}$ Agronomic Engineer, Ph.D. student at the Department of Entomology and Acarology, ESALQ/USP, CP 9, CEP 13418-900, Piracicaba, SP, Brazil. E-mail: silvamarcioalves@gmail.com

${ }^{3}$ Biologist, Ph.D., Post-doctoral fellow at the Department of Entomology and Acarology, ESALQ/USP, CP 9, CEP 13418-900, Piracicaba, SP, Brazil. E-mail: gcdbezerra@gmail.com

${ }^{4}$ Agronomic Engineer, Ph.D., Professor at the Department of Entomology and Acarology, ESALQ/USP, CP 9, CEP 13418-900, Piracicaba, SP, Brazil. E-mail: jdvendra@esalq.usp.br

${ }^{5}$ Agronomic Engineer, Ph.D., E-mail: thiagomastrangelo@gmail.com
} 
sistent with this hypothesis and are associated with growth regulation, an interference of reproduction and a reduction of the amount of protein synthesis and ovarian vitellogenesis, causing the inhibition of oogenesis and ovarian ecdysteroid synthesis (MORDUE (LUNTZ) et al., 2005).

\section{MATERIALS AND METHODS}

Insects. The specimens of $C$. capitata used in the experiments were obtained from laboratory colonies. C. capitata was reared according to the method of Carvalho and Nascimento (2002), with the exception that the adult diet was a mixture of hydrolysate protein and sugar (1:3).

Extract production. Neem kernels were obtained from the Empresa Baraúna Indústria e Comércio Ltda (Catanduva: 49 $1^{\circ}$ ' W $-21^{\circ} 7^{\prime} \mathrm{S}$ ); the branches and leaves of the neem tree were collected from the trees at the "Luiz de Queiroz" College of Agriculture (Piracicaba: $47^{\circ} 37^{\prime} \mathrm{W}-22^{\circ} 42^{\prime} \mathrm{S}$ ). The neem organs were dehydrated in a stove at $40{ }^{\circ} \mathrm{C}$ for 48 to $96 \mathrm{~h}$ and then crushed using a knife mill; the plant powders were kept in hermetically sealed glass flasks. The extraction was performed by maceration in an Erlenmeyer flask using $100 \mathrm{~g}$ of seed powder in $500 \mathrm{~mL}$ of deionized water for $72 \mathrm{~h}$. Every 24 $\mathrm{h}$, the material was filtered through voile cloth, the solution (extract + water) was returned to the Erlenmeyer flask, and $500 \mathrm{~mL}$ of deionized water was added. After $72 \mathrm{~h}$, the remaining cake was discarded. A lyophilizer (Pump Savant VLP $80^{\circledR}$ ) was used to produce the aqueous extracts from these solutions. Freeze-drying the extracts allows their storage, the calculation of the extraction yield and the dilution of the extracts, as a function of what was actually extracted, rather than dilution based on the initial weight of the material subjected to extraction, which avoids erroneous estimations of the sampling.

Organic extracts were then obtained (leaf extracts in methanol and branch extracts in dichloromethane) by subjecting the freeze-dried powders to Soxhlet extraction. A sample of approximately $200 \mathrm{~g}$ of powder from both organs were distributed in five Soxhlet extractors by placing $40 \mathrm{~g}$ of powder in a filter paper cartridge inside each extractor; 300 $\mathrm{mL}$ solvent was used for the leaf powder, and 200 $\mathrm{mL}$ was used for the branch powder. The powder was maintained in reflux with hexane, then in dichloromethane and, lastly, in methanol, always following the ascending order of polarity. This procedure was repeated until the total amount of extract from each plant organ and solvent were used. The extracts were then concentrated using a rotary evaporator at $40{ }^{\circ} \mathrm{C}$ under low pressure using a water tube. After this procedure, the extracts were stored in glass bottles and maintained in a laminar flow cabinet until the complete evaporation of the solvents. Based on a previous experiment (SILVA, unpublished data), the leaf extracts in methanol and branch extracts in dichloromethane were chosen for the bioassays. The assessment of the amount of azadirachtin in the extracts was performed according to Forim et al. (2010).

Sublethal effect of neem extracts on med-

flies. The 11 treatments were replicated four times and were distributed in a completely randomized design. The treatments were as follows: aqueous extract of kernels; leaf extract in methanol and branch extract in dichloromethane at three concentrations $(39,225$ and $888 \mathrm{ppm})$ and two controls (water and acetone - the solvent used for the dilution of the organic extracts). Plastic cages with $180 \mathrm{~mL}$ were used to evaluate the pre-oviposition period (from female emergence up to the first oviposition) and the fecundity, fertility and longevity of $C$. capitata. A hole was cut in the lids to allow the females to lay eggs; a Petri dish containing water was placed under the lid to receive the eggs that dropped from the voile cloth. A dental wick, in contact with 12.5 $\mathrm{mL}$ of extract or distilled water, was inserted into one side of the cages, serving as a source of water and treatment. Food for the adults was placed in small plastic caps. Two pairs of $C$. capitata were released per cage, which were environmentally controlled $\left(25 \pm 2^{\circ} \mathrm{C} ; 60 \pm 10 \% \mathrm{RH} ; 14 \mathrm{~h}\right.$ of photophase). The fecundity and longevity were evaluated daily. The eggs from the $1^{\text {st }}, 4^{\text {th }}, 8^{\text {th }}$ and $12^{\text {th }}$ day of oviposition were collected for the evaluation of fertility. These eggs were placed in Petri dishes over moistened filter paper covered by pieces of black cloth and kept in BOD $\left(25 \pm 2^{\circ} \mathrm{C} ; 60 \pm 5 \% \mathrm{RH} ; 14 \mathrm{~h}\right.$ of photophase $)$.

Statistical analyses. The longevity were subjected to variance analyze by the Kaplan-Meier method. To compare the survival empirical curves, tests were conducted, the Log-Rank (MANTEL, 1966) and the Wilcoxon (GEHAN, 1965; BRESLOW, 1970), considering the level of significance $\alpha$ $=0.05$. As we have in the total 11 treatments, it would be necessary to conduct 55 tests comparing $2 \times 2$, being necessary to use the Bonferroni correction for multiple comparisons to correction for type I error, and thus, the value of significance would be very low $\alpha=0.05 / 55=0.0009$. To solve this problem, it was used the clustering method in which the data were grouped into two different groups taking into account the average time of each treatment. The period of pre-oviposition, the fecundity (daily and total) and 
the fertility were subjected to a one-way analysis of variance (ANOVA). When significant differences were detected, the means were compared by the Tukey's honestly significant difference (HSD) test. The assumptions of homoscedasticity and normality of the residuals were verified using the Bartlett and Shapiro-Wilk tests, respectively. With respect to the assumptions, part of the data was transformed using the Box-Cox method (BOX; COX, 1964) before the analyses. The analyses were performed using the SAS 9.1 statistical software (SAS Institute, 2003).

\section{RESULTS AND DISCUSSION}

The extracts affected the longevity of $C$. capitata $($ Log-Rank $-p=0.008$ and Wilcoxon $-p=$ 0.043 ), caused similar effects on males and females $(\log -\operatorname{Rank}-p=0.249$ and Wilcoxon $-p=0.864)$ (Figure 1 and 2). In Figure 2, we can see that the average lifetimes are separated into two groups. The extracts affected the average lifetime between groups 1 and 2 (Log-Rank $-p<0.0001$ and Wilcoxon $-p<$ 0.0001 ) (Figure 3), however there is not difference between treatments within each group (Group 1: Log-Rank $-p=0.1606$ and Wilcoxon $-p=0.4424$ and Group 2: Log-Rank $-p=0.9981$ and Wilcoxon $-p=0.9658$ ) (Figure 4 and 5). Despite the fact that neem derivatives show low toxic effects against adults of Tephritidae fruit flies (BARRY et al., 2005; EFROM et al., 2011), their longevity can be reduced when the adults ingest the derivatives. DI ÍLIO et al. (1999) reported a reduction in the longevity of medflies in a dose-dependent manner when a neem seed extract was added to their diet. Other studies, including those on Rhagoletis indifferens Curran (VAN RANDEN; ROITBERG, 1998a), Bactrocera cucurbitae (Coquillet) and Bactrocera dorsalis (Hendel) (KHAN et al., 2007), corroborate this finding. Conversely, low concentrations are required to observe effects on reproduction. For example, DI ÍLIO et al. (1999) induced almost full sterility in C. capitata by applying $10,000 \mathrm{ppm}$ of neem aqueous extract to the diet; however, the females survived for only four days (usually the period during which the females begin to lay eggs). Therefore, there was an effect on longevity at $10,000 \mathrm{ppm}$ and $5,000 \mathrm{ppm}$, which produced longevity of only 9.4 days.

The pre-oviposition period of the females was not affected $(F=0.54 ; p=0.8490)$ (Table 1$)$; nevertheless, the daily fecundity was significantly affected $(F=3.32 ; p=0.0078)$ by the branch extract in dichloromethane $(888 \mathrm{ppm})$ throughout the life cycle of the females $(F=3.53 ; p=0.0016)$ (Table 2$)$. In addition, the extract in dichloromethane affected the egg viability (Table 3$)$. Initially, no significant effected was noted $(F=1.31 ; p=0.2653)$ on the $1^{\text {st }}$ day of oviposition (Table 3 ); however, during the peak of the oviposition period $\left(4^{\text {th }}\right.$ and $8^{\text {th }}$ day of oviposition), the effect was pronounced. On the $4^{\text {th }}$ day, the branch extract in dichloromethane $(888$ ppm) reduced the fertility of the females by $35.6 \%$, which was different from that induced by the aqueous extract of the seeds and the same branch extract in dichloromethane at the lower concentration (39 ppm) $(F=2.11 ; p=0.0525)$ (Table 3$)$. However, this reduction in fertility by the branch extract $(888 \mathrm{ppm})$ did not differ from that of the control (acetone at $5 \%$ ). On the $8^{\text {th }}$ day of oviposition, the effect of the branch extract in dichloromethane ( $888 \mathrm{ppm})$ on fertility was very pronounced and differed from the control $(F=$ $4.45 ; p=0.0005$ ) (Table 3$)$. The treatments did not differ significantly on the $12^{\text {th }}$ day of oviposition $(F=1.60 ; p=0.1506)$ (Table 3$)$.

It should be noted that the results obtained are valid for laboratory conditions. In the field, the low exposure of the adults is possible because the feeding inhibition would probably overwhelm the other physiological effects. Regardless, the effect on the females exposed to the branch extract in dichloromethane ( $888 \mathrm{ppm}$ ) was consistent. Previous investigations demonstrated significant reductions in C. capitata fecundity ( $>90 \%$ ), even when the flies were exposed to diets containing aqueous neem seed extract for only 24 h (DI ÍLIO et al., 1999). A similar effect was demonstrated in Rhagoletis indifferens Curran females; however, seven day-old flies are not affected when exposed to neem derivatives (VAN RANDEN; ROITBERG, 1998a). Within this context, it was propose that the physiological effect of neem derivatives on the reproduction of Tephritidae fruit flies may be irreversible; however, if the flies are exposed only after the initial phases of the gonotrophic cycle, the effect is negligible. In addition, the effects are pronounced only when the adults are exposed (VAN RANDEN; ROITBERG, 1998a; DI ÍLIO et al., 1999; SALLES; RECH, 1999; SINGH, 2003), and the effect may be negligible when immature specimens are exposed (see STARK et al., 1990). Insects that present high protein synthesis associated with reproduction, resulting in the production of yolk proteins during (completely or partially) the adult phase, may be more susceptible to sterilization when the adults are exposed. In contrast, insects that do not present intense vitellogenesis during the adult phase tend to show lower fecundity and fertility when the immature are exposed.

Such effects are probably related to interference with the endocrine control of 
development. Indeed, evidence indicates that azadirachtin affects the synthesis and/or release of ecdysteroids and juvenile hormones (MORDUE (LUNTZ) et al., 2005); in Diptera, the synthesis of vitellogenin is regulated by ecdysone (CHAPMAN, 1998). Histological observations revealed reductions in the ovary size of $C$. capitata (DI ILIO et al., 1999), B. cucurbitae and B. dorsalis, (KHAN et al., 2007), indicating that females exposed to neem derivatives presented immature ovaries when compared to the controls (DI ILIO et al., 1999; KHAN et al., 2007); however, the accessory glands of these species were not affected (DI ILIO et al., 1999; KHAN et al.,
2007), indicating sexual maturity and that limonoids may specifically affect the ovaries of Tephritidae fruit flies.

In this experiment, the insects copulated 48 to $72 \mathrm{~h}$ after emergence. Reports on the effects of neem compounds on insect males are very rare. Azadirachtin may induce physiological effects on the males, provoking spermatocyte degeneration in Mamestra brassicae L. (SHIMIZU, 1988) and halting spermatocyte cell division in Locusta migratoria L. (LINTON et al., 1997). Apparently, the males in the present study were not affected by neem limonoids, but further investigation is required.

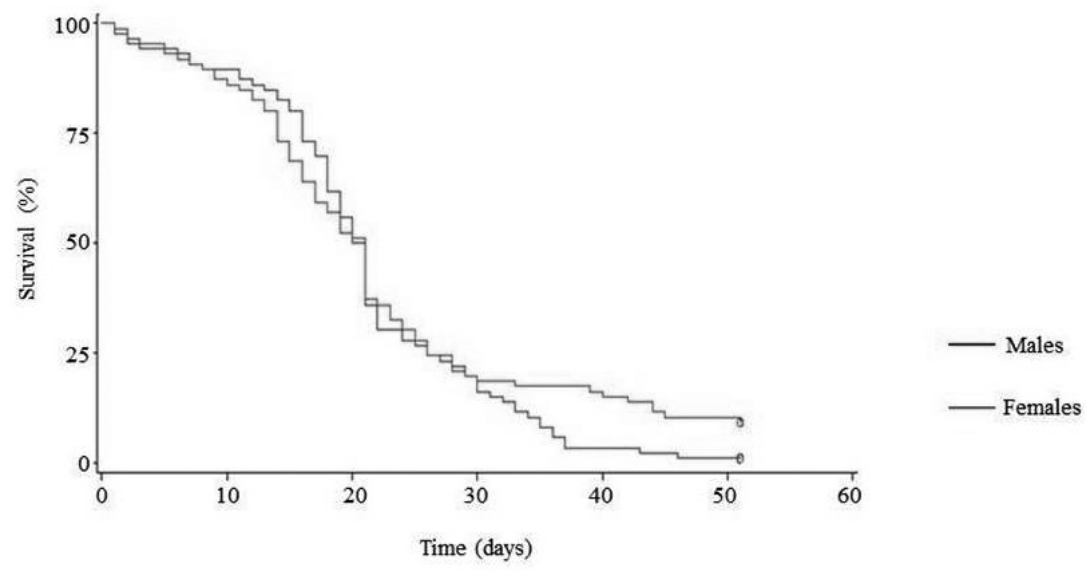

FIGURE 1 - Survival curves for males and females of Ceratitis capitata exposed to neem extracts.

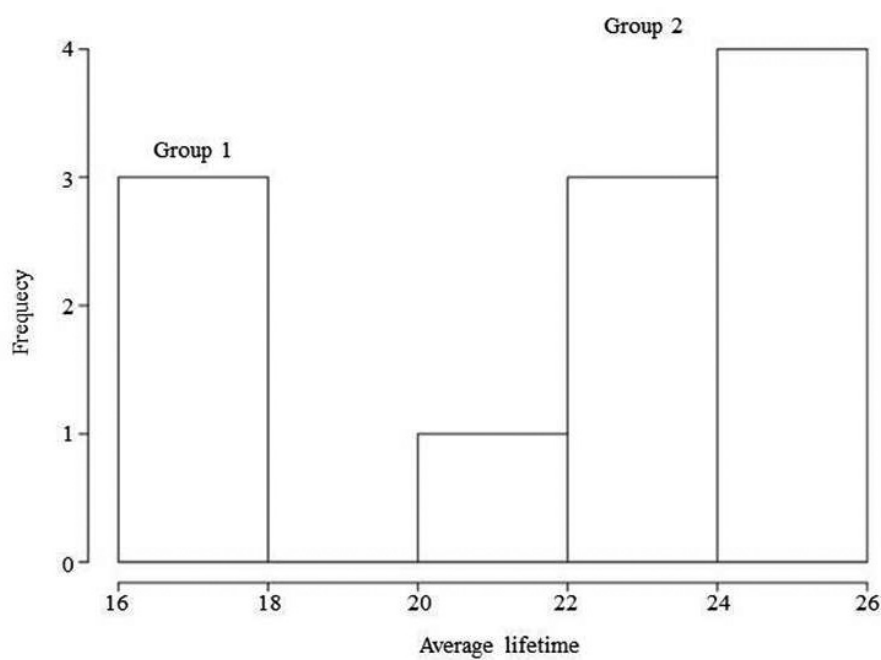

FIGURE 2 - Histogram of the average lifetime of treatments. Group 1: Extract of leaves in methanol (39 ppm); Extract of branches in dichloromethane (225 and 888 ppm). Group 2: Control 1 (deionized water); Control 2 (acetone - 5\%); Extract of seeds in water (39, 225 and 888 ppm); Extract of leaves in methanol (225 and $888 \mathrm{ppm})$; Extract of branches in dichloromethane (39 ppm). 


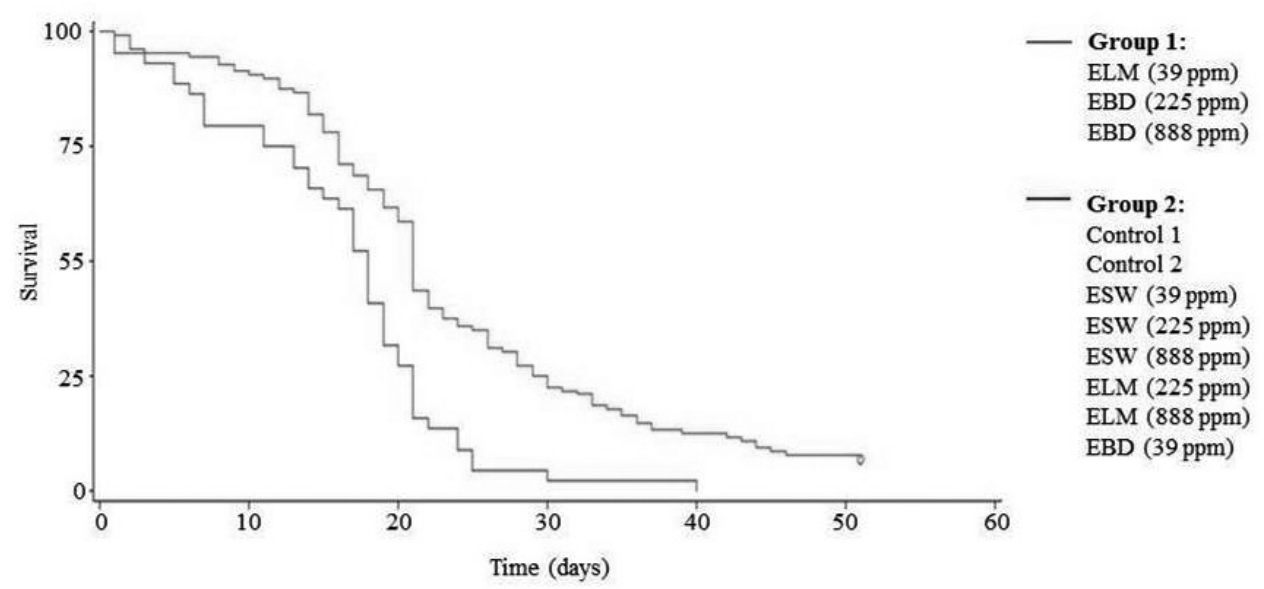

FIGURE 3 - Survival curves for groups 1 and 2 of Ceratitis capitata exposed to neem extracts.

Treatments: Control 1 (deionized water); Control 2 (acetone - 5\%); ESW: Extract of seeds in water; ELM: Extract of leaves in methanol; EBD: Extract of branches in dichloromethane.

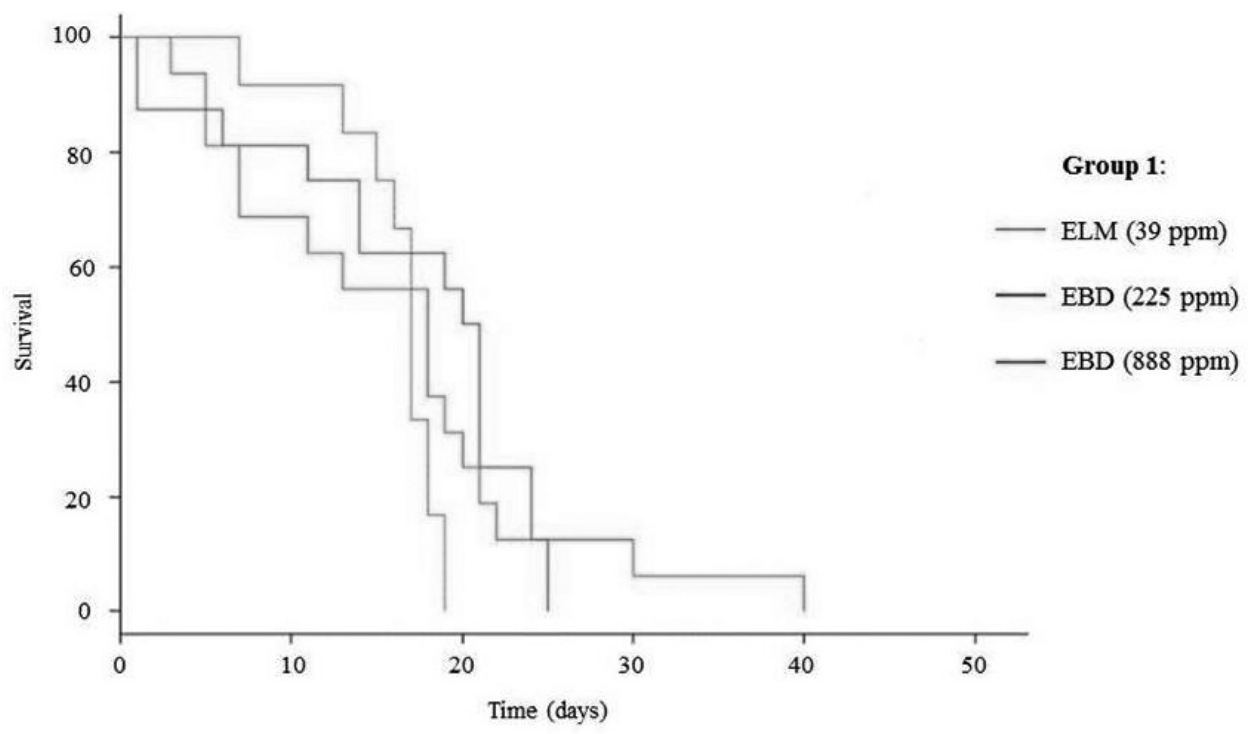

FIGURE 4 - Survival curves within group 1 of Ceratitis capitata exposed to neem extracts. Treatments: ELM: Extract of leaves in methanol; EBD: Extract of branches in dichloromethane. 


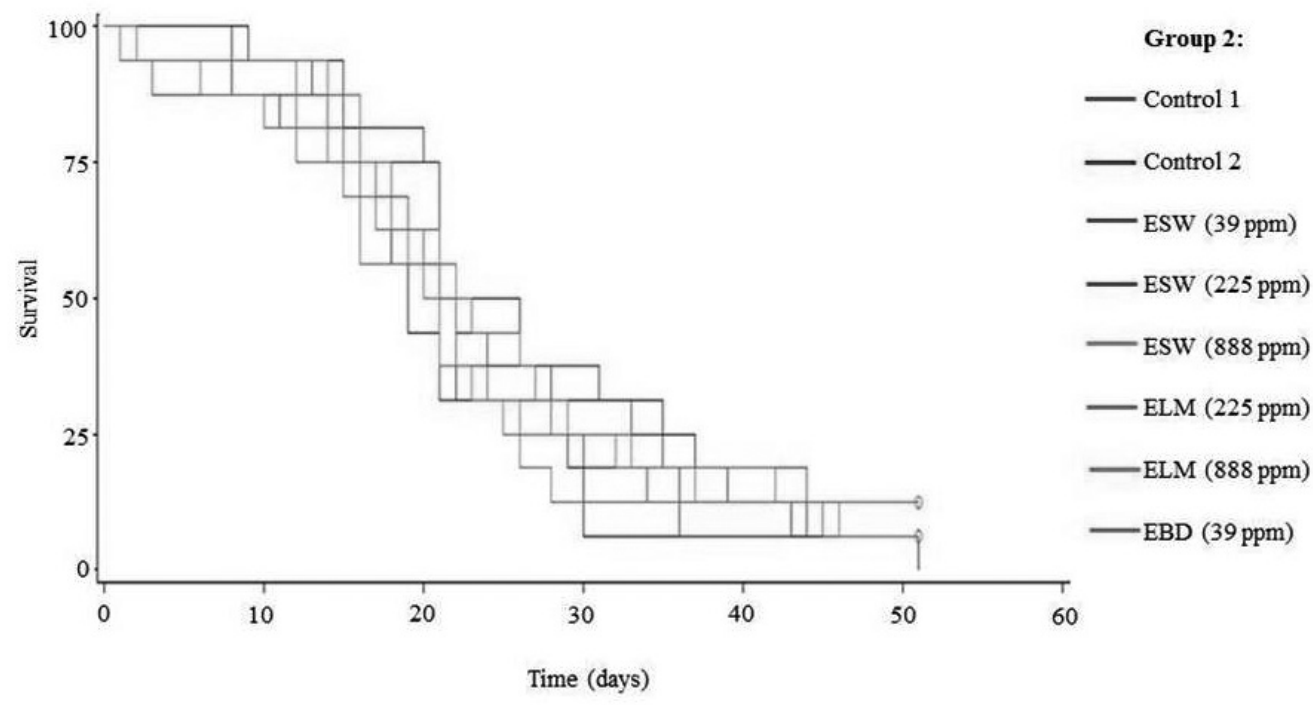

FIGURE 5 - Survival curves within group 2 of Ceratitis capitata exposed to neem extracts.

Treatments: Control 1 (deionized water); Control 2 (acetone - 5\%); ESW: Extract of seeds in water; ELM: Extract of leaves in methanol; EBD: Extract of branches in dichloromethane.

TABLE 1 - Pre-oviposition period ( \pm SE) of Ceratitis capitata exposed to neem extracts.

\begin{tabular}{lccc}
\hline \multicolumn{1}{c}{ Treatment } & & Azadirachtin (ppm) & Pre-oviposition period (days) \\
\hline Control (deionized water) & & - & $3.25 \pm 0.25$ \\
Control (acetone - 5\%) & 39 & 0.09539 & $3.25 \pm 0.25$ \\
& 225 & 0.55034 & $3.25 \pm 0.25$ \\
Extract of seeds in water & 888 & 2.17199 & $3.00 \pm 0.00$ \\
& 39 & 0.00002 & $3.25 \pm 0.25$ \\
Extract of leaves in methanol & 225 & 0.00013 & $3.50 \pm 0.29$ \\
& 888 & 0.00053 & $3.25 \pm 0.25$ \\
Extract of branches in dichloromethane & 225 & - & $3.00 \pm 0.00$ \\
F (treatments) & 888 & - & $3.50 \pm 0.29$ \\
Coefficient of variation (\%) & & & $3.25 \pm 0.25$ \\
\hline
\end{tabular}

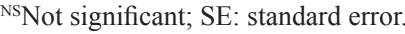

${ }^{1}$ The presence of azadirachtin was not detected in the dichloromethane branch extract. 
TABLE 2 - Fecundity ( \pm SE) of Ceratitis capitata exposed to neem extracts.

\begin{tabular}{|c|c|c|c|}
\hline \multicolumn{2}{|c|}{ Treatment (azadirachtin) } & $\begin{array}{c}\text { Fecundity } \\
\text { (min. - max.) }\end{array}$ & $\begin{array}{l}\text { Fecundity daily }{ }^{2,3} \\
\quad \text { (min. - max.) }\end{array}$ \\
\hline \multicolumn{2}{|c|}{ Control (deionized water) } & $661.1 \pm 56.4 \quad$ a $\quad(515.5-789.5)$ & $30.6 \pm 1.9$ a $(25.3-34.3)$ \\
\hline \multicolumn{2}{|c|}{ Control (acetone - 5\%) } & $678.6 \pm 215.6$ a $\quad(377.0-1,316.0)$ & $31.9 \pm 3.7$ a $(25.1-42.4)$ \\
\hline \multirow{3}{*}{$\begin{array}{l}\text { Extract of seeds } \\
\text { in water }\end{array}$} & $39(0.09539)$ & $(524.5-1,177.0)$ & $34.6 \pm 3.5$ a $(30.8-38.0)$ \\
\hline & $225(0.55034)$ & $(312.5-1,293.5)$ & $28.7 \pm 5.8$ a $(20.8-40.4)$ \\
\hline & $888(2.17199)$ & $557.0 \pm 186.5 \mathrm{ab}(245.0-1,005.5)$ & $23.3 \pm 3.0 \mathrm{ab}(14.1-34.7)$ \\
\hline \multirow{3}{*}{$\begin{array}{l}\text { Extract of leaves } \\
\text { in methanol }\end{array}$} & $39(0.00002)$ & $412.4 \pm 137.7 \mathrm{ab}(257.0-825.0)$ & $33.2 \pm 4.7$ a $(17.7-64.2)$ \\
\hline & $225(0.00013)$ & $405.7 \pm 32.1 \quad$ ab $(321.5-471.0)$ & $25.1 \pm 1.0 \mathrm{ab}(17.9-31.1)$ \\
\hline & $888(0.00053)$ & $509.5 \pm 130.8 \mathrm{ab}(287.0-806.0)$ & $21.5 \pm 4.5 \mathrm{ab}(17.9-36.6)$ \\
\hline \multirow{3}{*}{$\begin{array}{l}\text { Extract of branches } \\
\text { in dichloromethane }\end{array}$} & 39 & $641.1 \pm 157.2$ a $(196.5-927.0)$ & $27.5 \pm 5.8 \mathrm{ab}(14.0-26.9)$ \\
\hline & 225 & $408.4 \pm 56.7 \quad$ ab $(274.5-545.0)$ & $18.0 \pm 1.3 \mathrm{ab}(18.3-26.0)$ \\
\hline & 888 & b $\quad(118.0-212.5)$ & $12.7 \pm 0.8$ b $(7.9-17.7)$ \\
\hline \multicolumn{2}{|l|}{ F (treatments) } & $3.53 * *$ & $3.32 * *$ \\
\hline \multicolumn{2}{|c|}{ Coefficient of variation (\%) } & 8.10 & 9.87 \\
\hline
\end{tabular}

** Significant; SE: standard error.

${ }^{1}$ The presence of azadirachtin was not detected in the dichloromethane branch extract.

${ }^{2}$ Means followed by different letters in the columns differ by Tukey's test $(\mathrm{p}<0.05)$.

${ }^{3}$ Original means are presented in this table. For analysis, the data were transformed using " $\lambda=\log _{10}(\mathrm{x})$ ".

TABLE 3 - Fertility ( \pm SE) of Ceratitis capitata exposed to neem extracts.

\begin{tabular}{|c|c|c|c|c|c|}
\hline \multirow{2}{*}{\multicolumn{2}{|c|}{ Treatment (azadirachtin) }} & \multicolumn{4}{|c|}{ Fertility $(\%)$} \\
\hline & & \multirow{2}{*}{$\frac{1^{\text {st }} \text { day }}{98.9 \pm 0.8}$} & $4^{\text {th }}$ day $^{2}$ & $8^{\text {th }}$ day & \multirow{2}{*}{$\frac{12^{\text {th }} \text { day }}{74.1 \pm 9.0}$} \\
\hline Control (deionized wate & & & $80.6 \pm 5.7 \quad a b$ & $87.3 \pm 4.6 \quad a b$ & \\
\hline Control (acetone - 5\%) & & $88.1 \pm 3.6$ & $79.1 \pm 9.4 \quad \mathrm{ab}$ & $88.6 \pm 7.5 \quad a b$ & $73.4 \pm 12.4$ \\
\hline \multirow{3}{*}{$\begin{array}{l}\text { Extract of seeds } \\
\text { in water }\end{array}$} & $39(0.09539)$ & $83.5 \pm 2.5$ & $70.9 \pm 17.0 \mathrm{ab}$ & $89.4 \pm 3.3 \mathrm{ab}$ & $76.4 \pm 9.7$ \\
\hline & $225(0.55034)$ & $93.1 \pm 5.4$ & $87.2 \pm 3.5 \quad a b$ & $93.1 \pm 4.5 \quad a b$ & $86.2 \pm 1.3$ \\
\hline & 888 (2.17199) & $96.9 \pm 1.0$ & $91.9 \pm 5.0 \quad \mathrm{a}$ & $73.2 \pm 9.3 \mathrm{abc}$ & $67.2 \pm 15.5$ \\
\hline \multirow{3}{*}{$\begin{array}{l}\text { Extract of leaves } \\
\text { in methanol }\end{array}$} & $39(0.00002)$ & $65.0 \pm 22.2$ & $86.8 \pm 5.5 \mathrm{ab}$ & $91.2 \pm 2.3 \mathrm{ab}$ & $83.9 \pm 7.3$ \\
\hline & $225(0.00013)$ & $82.5 \pm 8.9$ & $82.5 \pm 8.8 \quad a b$ & $86.5 \pm 6.8 \mathrm{ab}$ & $83.5 \pm 6.2$ \\
\hline & $888(0.00053)$ & $93.9 \pm 3.3$ & $86.1 \pm 4.6 \quad a b$ & $96.9 \pm 1.1 \quad a$ & $84.2 \pm 4.9$ \\
\hline \multirow{3}{*}{$\begin{array}{l}\text { Extract of branches } \\
\text { in dichloromethane }\end{array}$} & 39 & $86.8 \pm 4.9$ & $92.4 \pm 1.9$ a & $84.4 \pm 5.7 \quad a b c$ & $57.3 \pm 6.0$ \\
\hline & 225 & $84.8 \pm 8.5$ & $71.6 \pm 13.9 \mathrm{ab}$ & $64.3 \pm 11.5 \mathrm{bc}$ & $39.5 \pm 11.1$ \\
\hline & 888 & $92.9 \pm 2.5$ & $43.6 \pm 14.6 \mathrm{~b}$ & $55.2 \pm 2.4 \quad \mathrm{c}$ & $67.4 \pm 11.4$ \\
\hline \multicolumn{2}{|l|}{ F (treatments) } & $1.31^{\mathrm{NS}}$ & $2.11 * *$ & $4.45^{* *}$ & $1.60^{\mathrm{NS}}$ \\
\hline \multicolumn{2}{|c|}{ Coefficient of variation (\%) } & 18.39 & 34.08 & 14.69 & 44.41 \\
\hline
\end{tabular}

\footnotetext{
${ }^{\mathrm{NS}}$ Not significant; **Significant; SE: standard error.

${ }^{1}$ The presence of azadirachtin was not detected in the dichloromethane branch extract.
}

${ }^{2}$ Means followed by different letters in the columns differ by Tukey's test $(\mathrm{p}<0.05)$. 


\section{CONCLUSIONS}

Neem extracts induce sublethal effects in Ceratitis capitata adults. The fecundity and fertility were reduced when the medfly females were exposed to branch extracts in dichloromethane at concentrations higher than $888 \mathrm{ppm}$. The adult longevity was reduced when medfly were exposed to the leaves extract in methanol (39 ppm) and branch extract in dichloromethane (225 and $888 \mathrm{ppm}$ ). However, the pre-oviposition period of the females were unaffected by treatment with the aqueous extract of the seeds, the branch extract in dichloromethane and the leaf extract in methanol when provided as water sources at concentrations up to $888 \mathrm{ppm}$.

\section{ACKNOWLEDGMENTS}

We thank the National Council for Scientific and Technological Development $(\mathrm{CNPq})$ for providing a fellowship to MAS (Proc. 133471/2008-0) and a research grant to JDV (Proc. 305811/2009-6). This article is part of the M.S. thesis of MAS (University of São Paulo, "Luiz de Queiroz" College of Agriculture) directed by JDV.

\section{REFERENCES}

BARRY, J. D.; SCIARAPPA, W. J.; TEIXEIRA, L. A. F.; POLAVARAPU, S. Comparative effectiveness of different insecticides for organic management of blueberry maggot (Diptera: Tephritidae). Journal of Economic Entomology, Lanham, v.98, n.4, p.12361241, 2005.

BRESLOW, N. A generalized Kruskal-Wallis test for comparing $\mathrm{K}$ samples subject to unequal patterns of censorship. Biometrika, London, v.57, n.3, p.579594, 1970.

CARVALHO, R. S.; NASCIMENTO, A. S. Criação e utilização de Diachasmimorpha longicaudata para controle biológico de moscas-das-frutas (Tephritidae). In: PARRA, J. R. P.; BOTELHO, P. S. M.; CORRÊA-FERREIRA, B. S.; BENTO, J. M. S. (Ed.). Controle biológico no Brasil: parasitoides e predadores. São Paulo: Manole, 2002. p. 165-179.

CHAPMAN, R. F. The insects: structure and function. Cambridge: Cambridge University Press, 1998. p. 770.
CHEN, C.; DONG, Y.; CHENG, L.; HOU, R. F. Deterrent effect of neem seed kernel extract on oviposition of the oriental fruit fly (Diptera: Tephritidae) in guava. Journal of Economic Entomology, Lanham, v.89, n.2, p.462-466, 1996.

DI ILIO, V.; CRISTOFARO, M.; MARCHINI, D.; NOBILI, P.; DALLAI, R. Effects of a neem compound on the fecundity and longevity of Ceratitis capitata (Diptera: Tephritidae). Journal of Economic Entomology, Lanham, v.92, n.1, p.76-82, 1999.

EFROM, C. F. S.; REDAELLI, L. R.; MEIRELLES, R. N.; OURIQUE, C. B. Laboratory evaluation of phytosanitary products used for control of the South American fruit fly, Anastrepha fraterculus, in organic farming. Crop Protection, Kidlington, v.30, n.9, p.1.162-1.167, 2011.

FORIM, M. R.; MATOS, A. P.; DA SILVA, M. F. G. F.; CASS, Q. B.; VIEIRA, P. C.; FERNANDES, J. B. Uso de CLAE no controle de qualidade em produtos comerciais de nim: reprodutibilidade da ação inseticida. Química Nova, São Paulo, v.33, n.5, p.1.082-1.087, 2010

GEHAN, E. A. A Generalized Wilcoxon Test for Comparing Arbitrarily Singly-Censored Samples. Biometrika, London, v. 52, n.1/2, p.203-223, 1965.

KHAN, M.; HOSSAIN, A. M.; ISLAM, S. M. Effects of neem leaf dust and a commercial formulation of a neem compound on the longevity, fecundity and ovarian development of the melon fly, Bactrocera cucurbitae (Coquillett) and the oriental fruit fly, Bactrocera dorsalis (Hendel) (Diptera: Tephritidae). Pakistan Journal of Biological Sciences, Faisalabad, v.10, n.20, p.3.656-3.661, 2007.

LINTON, Y. M.; NISBET, A. J.; MORDUE (LUNTZ), A. J. The effects of azadirachtin on the tests of the desert locust, Schistocerca gragaria. Journal of Insect Physiology, Oxford, v.43, n.11, p.1.077-1. 084, 1997.

MANTEL, N. Evaluation of survival data and two new rank order statistics arising in its consideration. Cancer Chemotherapy Reports, Bethesda, v.50, p.163-170, 1967. 
MORDUE (LUNTZ), A.J.; MORGAN, E.D.; NISBET, A.J. Azadirachtin, a natural product in insect control. In: GILBERT, L.I.; IATROU, K.; GILL, S.S. Comprehensive molecular insect science. Amsterdam: Elsevier, 2005. p. 117-134.

SALLES, L. A.; RECH, N. L. Efeito de extratos de nim (Azadirachta indica) e cinamomo (Melia azedarach) sobre Anastrepha fraterculus (Wied.) (Diptera: Tephritidae). Revista Brasileira de Agrociência, Pelotas, v.5, n.3, p. 225-227, 1999.

SAS Institute. Statistical analysis system: version 9.1. Cary, 2003.

SHIMIZU, T. Suppressive effects of azadirachtin on spermiogenesis of the diapausing cabbage armyworm, Mamestra brassicae, in vitro. Entomologia Experimentalis et Applicata, Dordrecht, v. 46, n.2, p. 197-199, 1988.

SILVA, M. A.; ALVARENGA, C. D.; BEZERRASILVA, G. C. D.; MASTRANGELO, T.; LOPESMIELEZRSKI, G. N.; GIUSTOLIN, T. Toxic effects of neem seed cake on the larval-pupal (prepupal) stage of Mediterranean fruit fly (Diptera: Tephritidae). Fruits, Paris, v.66, n.5, p.363-369, 2011.

SINGH, S. Effects of aqueous extract of neem seed kernel and azadirachtin on the fecundity, fertility and post-embryonic development of the melonfly, Bactrocera cucurbitae and the oriental fruit fly, Bactrocera dorsalis (Diptera: Tephritidae), Journal of Applied Entomology, Malden, v.127, n.9, p.540547, 2003.
SINGH, S.; SINGH, R. P. Neem (Azadirachta indica) seed kernel extracts and azadirachtin as oviposition deterrents against the melon fly (Bactrocera cucurbitae) and the oriental fruit fly (Bactrocera dorsalis). Phytoparasitica, Bet Dazan, v.26, n.3, p.191-197, 1998.

STARK, J. D.; VARGAS, R. I.; THALMAN, R. K. Azadirachtin: effects on metamorphosis, longevity, and reproduction of three tephritid fruit fly species (Diptera: Tephritidae), Journal of Economic Entomology, Lanham, v.83, n.6, p.2.168-2.174, 1990.

STEFFENS R. J.; SCHMUTTERER, H. The effects of a crude methanolic neem (Azadirachta indica) seed kernel extract on metamorphosis and quality of adults of the Mediterranean fruit fly, Ceratitis capitata Wied. (Dip: Tephritidae). Zeitschrift für Angewandte Entomologie, Hamburg, v.94, n.1-5, p. 98-103, 1982.

Van RANDEN, E.J.; ROITBERG, B.D. Effect of a neem (Azadirachta indica) based insecticide on oviposition deterrence, survival, behavior and reproduction of adult western cherry fruit fly (Diptera: Tephritidae). Journal of Economic Entomology, London, v.91, n.1, p.123-131, 1998a.

Van RANDEN, E. J. V.; ROITBERG, B. D. The effect of a neem (Azadirachta indica) based insecticide on survival and development of juvenile western cherry fruit fly (Rhagoletis indifferens) (Diptera: Tephritidae). Canadian Entomologist, Ottawa, v.130, n.6, p.869-876, 1998 b. 